KARL MARX 


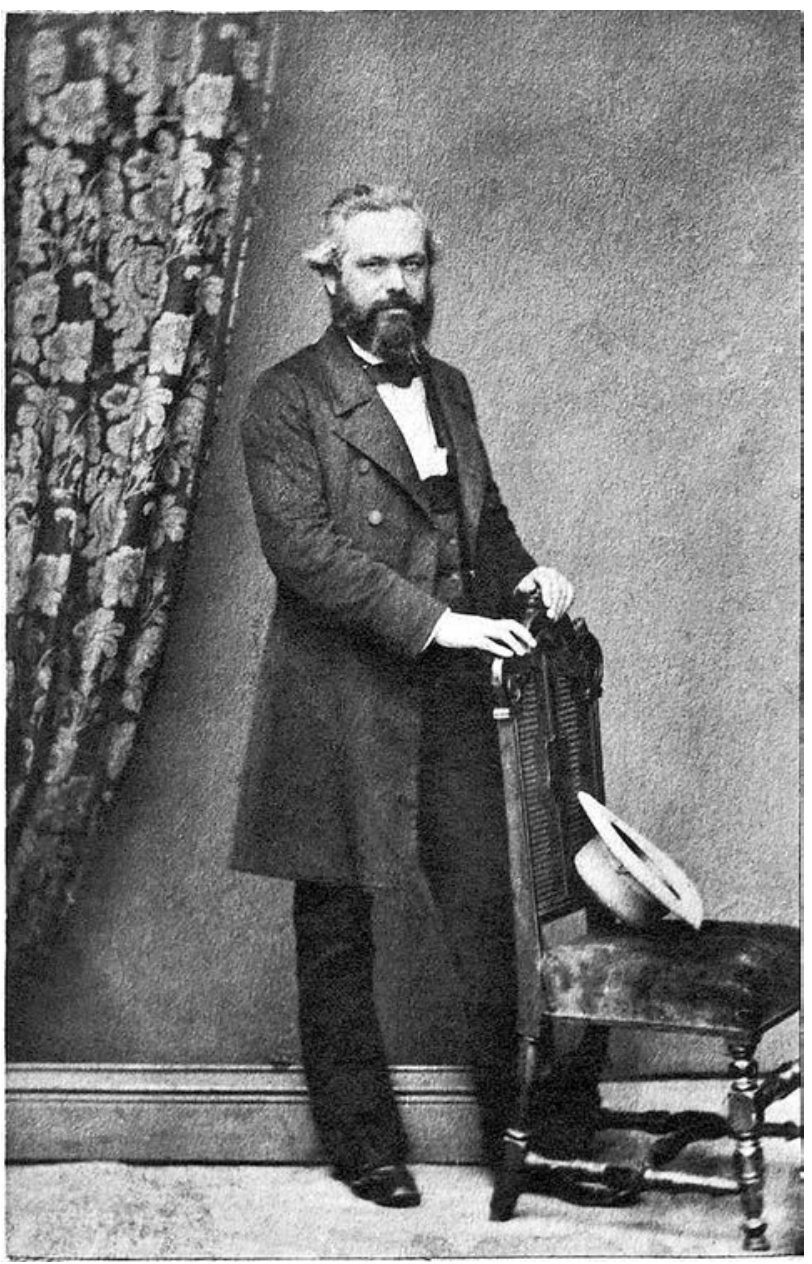




\title{
Karl Marx
}

\author{
Pbilosopby \\ and Revolution
}

SHLOMO AVINERI

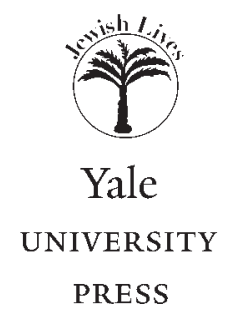


Frontispiece: Karl Marx, around I860

Copyright (C) 2019 by Shlomo Avineri.

All rights reserved.

This book may not be reproduced, in whole or in part, including illustrations, in any form (beyond that copying permitted by Sections 107 and Io8 of the U.S.

Copyright Law and except by reviewers for the public press), without written permission from the publishers.

Yale University Press books may be purchased in quantity for educational, business, or promotional use. For information, please e-mail sales.press@yale.edu (U.S. office) or sales@yaleup.co.uk (U.K. office).

Set in Janson type by Integrated Publishing Solutions. Printed in the United States of America.

ISBN 978-0-300-2II70-2 (hardcover : alk. paper)

Library of Congress Control Number: 2018963640

A catalogue record for this book is available from the British Library.

This paper meets the requirements of ANSI/NISO Z Z39.48-1992

(Permanence of Paper).

I0 98765432 I 